\title{
Micro-história italiana e jornalismo em Expectativa de vida: vinte anos e Mães vivas de uma geração morta
}

\section{Italian microhistory and journalism in Expectativa de vida: vinte anos and Mães vivas de uma geração morta}

Francisco Aquinei Timóteo Queirós ${ }^{1}$ 


\title{
Resumo
}

O presente artigo é resultado das discussões desenvolvidas na tese intitulada "Brechas da narrativa e profundezas do cotidiano: micro-história italiana e jornalismo em $O$ olho da rua, de Eliane Brum"2. A investigação busca refletir sobre a prática jornalística de Eliane Brum em $O$ olho da rua. O estudo propõe a aproximação entre a metodologia micro-histórica e os pressupostos do jornalismo, visando discutir a presença dos sujeitos comuns nas reportagens Expectativa de vida: vinte anos e Mães vivas de uma geração morta. Para tanto, a pesquisa ancora-se nos estudos de Carlo Ginzburg (2007), Carlo Ginzburg e Poni (1991), Jacques Revel (2010), Giovanni Levi (1992, 2016) e Henrique Espada Lima (2006).

Palavras-chave

Eliane Brum, micro-história, jornalismo, O olho da rua.

\begin{abstract}
\end{abstract}
This article is the result of discussions developed during the doctoral program called "Brechas da narrativa e profundezas do cotidiano: micro-história italiana e jornalismo em O olho da rua, de Eliane Brum". The investigation reflects on the journalistic practice of Eliane Brum in $O$ olho da rua. The study proposes the approximation between the micro-historical methodology and the assumptions of journalism, aiming to discuss the presence of common subjects in the reports Expectativa de vida: vinte anos and Mães vivas de uma geração morta. Therefore, the research is anchored in the studies of Carlo Ginzburg (2007) Carlo Ginzburg and Poni (1991), Jacques Revel (2010), Giovanni Levi (1992, 2016) and Henrique Espada Lima (2006).

\section{Keywords}

Eliane Brum, micro history, journalism, O olho da rua. 


\section{Introdução}

Eliane Brum trabalha com o deslindamento dos sentidos culturais e sociais de variados sujeitos e grupos. Desse modo, a prática da repórter gaúcha afasta-se da lógica etnocêntrica, optando pelas realidades embaciadas, opacas, marginalizadas. Aproxima-se, portanto, das proposições analíticas defendidas por Ginzburg, Levi e Grendi - no que tange ao destrinchamento do estar no mundo, tendo por finalidade estabelecer um olhar concentrado sobre as pistas abandonadas pelos sujeitos sociais, suas histórias e seus relatos.

A microanálise emerge como uma importante matriz investigativa para a compreensão dos indivíduos e dos grupos frente às conexões econômicas, culturais e sociais. Lima (2006) remete à fortuna crítica de Edoardo Grendi para observar que o percurso delineado pela microanálise tenta compreender como se estabelecem os nexos de estruturação e integração dos contextos sociais, buscando "recuperar a espessura da sociedade por meio do estudo dos agrupamentos que a constituem" (LIMA, 2006, p. 197).

O interesse de Grendi não se apresenta como um dado apriorístico, mas direciona-se para a compreensão da dinâmica da mudança social. Nesse sentido, suas inquietações não estão vinculadas estritamente ao modo como a sociedade está organizada, mas em assimilar os processos que a afetam e a modificam. Sob a influência dos estudos de Fredrik Barth, Grendi delimita as formas assumidas pela sociedade por meio da construção de modelos "generativos" - que buscam dar conta do caráter inteligível e descritivo dos processos gerados a partir de uma situação histórico-social específica.

O caminho delineado por Grendi - aponta Lima (2006) - parte da antropologia econômica para a microanálise histórica. Guarda, nessa lógica, uma correspondência de procedimento, "pensando por meio das possibilidades e dos limites da análise documental" (LIMA, 2006, p. 198) e promove o "cruzamento intensivo de fontes nominais dentro de um contexto espacial circunscrito" (LIMA, 2006, p. 198).

Esses aspectos podem ser observados analogamente nas reportagens Expectativa de vida: vinte anos e Mães vivas de uma geração morta, presentes 
no livro O olho da rua, de Eliane Brum. A microanálise possibilita - no âmbito do presente artigo - refletir sobre o exercício da prática jornalística, sobre as solidariedades, sobre as interações e, principalmente, acerca das dinâmicas de transformações sociais. O movimento permite reconstituir por meio do nome e da análise de práticas individuais o relato de contextos sociais diversos.

A força analógica que move as reportagens em estudo é conduzida pela energia cognitiva da abordagem microanalítica e pelo distanciamento das bases universalizantes referentes aos ambientes sociais. Lima (2006) assinala em conversa com o pensamento de Grendi - que há uma intensificação das investigações microscópicas e, na mesma medida, a busca por compreender de forma aprofundada as relações contextuais.

\section{Expectativa de vida: vinte anos}

Na reportagem Expectativa de vida: vinte anos fica patente o direcionamento do olhar da jornalista Eliane Brum em direção a escala reduzida, circunscrita. A microanálise possibilita compreender o contexto relatado não a partir da tessitura dos estereótipos e lugares-comuns que rotineiramente revestem as representações sobre as favelas e as periferias. Pelo contrário, a mudança de angulação assumida pela repórter permite espiar a realidade sob a ótica dos sujeitos e de suas experiências - tendo por finalidade assimilar as incongruências, lacunas e problemáticas advindas de contextos sociais específicos.

No texto, Brum (2008) escrutina a vida de Sérgio Cláudio de Oliveira Teixeira, o "Serginho Fortalece". Sérgio Cláudio é um dos dezessete rapazes que aparecem no filme Falcão - meninos do tráfico, exibido no Fantástico em 2006. Segundo Brum (2008), o documentário não mostrou na tela de TV uma realidade desconhecida para os brasileiros - da favela e da "pista" (dos condomínios) -, porém, impôs a necessidade de ver.

Ao discutir a realidade de "Serginho Fortalece", Brum deposita uma atenção mais detida sobre a violência social vivida por uma grande parcela da juventude brasileira nas periferias e favelas do país. Para a autora de O olho da rua, 
o documentário Falcão - Meninos do Tráfico, de MV Bill e Celso Athayde, exibido pelo Fantástico, possibilitou deslocar o olhar da posição de assistir (passiva) para o de ver (problemática).

A figura de Sérgio Cláudio de Oliveira Teixeira surge como microcosmo de um acontecimento que se repete em diferentes favelas pelo país. No Brasil, cuja expectativa de vida gira em torno de 75,5 anos, uma geração inteira de garotos pobres morre antes de completar vinte anos de idade.

Brum observa que o nome constitui sentidos, lugares e significados. O nome situa. Seguindo esse raciocínio, a autora de $A$ vida que ninguém vê (2006) estruturou a reportagem Expectativa de vida: vinte anos sob o ponto de vista de "Serginho Fortalece". Ao refletir sobre a construção da matéria, Brum (2008) demonstra sua inquietação pela necessidade reiterada por novas fontes, pelo reexame do local narrado e pela complexificação constante da reportagem. A jornalista ressalta que se não fizer "esse derradeiro esforço, [...] fico remoendo a certeza de que perdi a melhor informação da matéria - e nem sequer vou saber qual é" (BRUM, 2008, p. 238).

Esse movimento de minúcias e desentranhamento pode ser observado na conversa que Brum estabelece com a tia de Fortalece - que confidencia à repórter que o nome escolhido, inicialmente, para o batismo do sobrinho seria "Gênesis":

Eu acabara de descobrir como contaria a história do único sobrevivente do Falcão. Pelos nomes - essa era a chave do texto e da vida. Já no primeiro registro o desejo da mãe foi ignorado pelo pai, que impôs seu próprio nome no cartório. E assim foi tecida, entre nomes e "vulgos" - desejos e destinos contidos em nomes e vulgos -, a história do sobrevivente. (BRUM, 2008, p. 238)

Andréa Cristiana Santos (2014) ressalta que a "descoberta" de grupos sociais subalternos no âmbito de práticas cotidianas colabora para o desvelamento de pistas na opacidade da realidade. Nessa acepção, ancorando-se na perspectiva ginzburgiana, Santos (2014) pondera que o nome atua na reconfiguração do vivido e no "resgate" das experiências caladas e apagadas. 
De modo semelhante, Eliane Brum (2008) fia-se na compreensão dos traços, erros e espias para "apresentar" a realidade de "Fortalece". Ao se ancorar no nome, a autora de $A$ vida que ninguém vê adentra por meio da microanálise as zonas invisíveis do contexto social, articulando-as por meio do relato do vivido, de modo que Brum não se restringe à superfície da narrativa, mas se aprofunda na complexidade da vida humana.

Ao selecionar Sérgio Cláudio de Oliveira Teixeira para explicitar uma realidade, Brum se afasta da frieza das estatísticas - que apenas encarnam números desprovidos de um sentido social - e busca, pelo contrário, no confronto com a existência de "Serginho Fortalece", compreender a representatividade e singularidade do sujeito, lendo-o a partir de seu mundo, nas margens da periferia e da favela, como sujeito histórico.

Ao articular a linguagem, as particularidades e apresentar o desenho social e cultural da favela, Brum propõe um relato que se distancia das representações estereotipadas da periferia. A constituição da narrativa jornalística não parte de um a priori, como algo dado e resolvido, mas como zona aberta, como território de disputa de sentidos. Para o deciframento da realidade, é necessário deslocar o campo de visão, ou, assumindo os termos propostos por Ginzburg, estabelecer um "novo modo de ver" (2007, p. 240).

A "formação" de "Serginho Fortalece" para o tráfico de drogas tem como referência a figura paterna. O pai foi expulso da favela porque cheirava mais cocaína do que o dinheiro que ganhava. Quando retornou, levou Fortalece para a boca. Aos dez anos, o menino já era o falcão (o olheiro, o vigia) do pai. Esse "seguir os passos do pai" vem marcado por representações de poder. Fortalece comenta na reportagem que o pai andava cheio de dinheiro e de mulheres - e que seu sonho era ser semelhante ao Sérgio pai.

Aos doze anos Fortalece segurou a primeira arma. Brum (2008) reconstrói o relato por meio da articulação e desentranhamento da linguagem de Serginho. Ao empunhar a primeira pistola, Sérgio Cláudio diz que se sentiu "um bambambã", cheio de coragem e força. Os meninos que o agrediam com cascudos passaram 
a respeitá-lo e as mulheres se aproximaram - "mulher se perde mesmo é por arma e por dinheiro. Mulher de favela, não sei mulher de fora. Mas de favela não pode ver um homem com uma pistola, um fuzil, um cordãozinho de ouro no pescoço" (BRUM, 2008, p. 194).

A arquitetura singularizada dos contextos sociais, culturais e históricos permite compreender a realidade experimentada por "Serginho Fortalece" como fluida e aberta. A escala reduzida propicia, também, focalizar com maior exatidão as complexidades, as incertezas e a representatividade de Fortalece. Esse percurso é observado quando Brum descreve as particularidades do menino do tráfico. A boca de fumo que Fortalece guardava, por exemplo, ficava ao lado da casa da avó:

O nome falcão, segundo MV Bill, vem de parte do Sudeste e do Sul do país. Emprestado de uma ave de rapina, no topo da cadeia alimentar, o título é glamoroso para uma atividade exaustiva, perigosa e muito mal remunerada. São apenas garotos com medo, de arma na mão. Fortalece trabalhava do meio-dia às seis horas, com meia hora de descanso no final da tarde, chovesse ou fizesse sol. Ganhava 350 reais por mês e, se dormisse no posto e a polícia ocupasse o morro, era executado pelos colegas. "Entrei no pó para conseguir ficar acordado. Era uma vida doida", diz. Mesmo assim, dormia. A avó gritava, da janela, apavorada: "Polícia, polícia". Fortalece então pegava o radinho, empunhava o fuzil: "Fortalece no ar. Uma viatura [...]". (BRUM, 2008, p. 194-195)

A irmã Cibelle ficou encarregada de cuidar de Sérgio Cláudio quando a mãe morreu. Ela diz que Fortalece quase foi morto umas três vezes: "Uma vez me avisaram que estavam matando ele, afogando a cabeça dele. Eu estava tão cansada que disse para deixar matar. No outro dia fui só agilizar o enterro, mas ele estava vivo" (BRUM, 2008, p. 195). Raimunda, a mãe de Serginho, queria que o filho fosse palhaço. Brum (2008) conjectura que talvez por viver cercada pelos presságios que vinham "dos caras da boca" e da polícia, Raimunda quisesse manter o filho a salvo e vivo de alguma maneira. Quando Serginho Fortalece era mais jovem, Raimunda tentou levá-lo ao circo, entretanto não conseguiu entrar: 
Muito antes dessa cena levou os três filhos pela mão até a porta de um cirquinho mambembe, daqueles quase tristes. Mas o dinheiro não deu. Fortalece não lembra, enfiou essa memória doída não sabe onde. Cibelle recorda bem. "A gente chegou até bem pertinho da lona, que estava entreaberta. A gente viu os palhaços e um homem puxando um elefante", diz. "Aí a mãe não conseguiu pagar, coitada. O Sérgio Cláudio era pequeno. Chorou tanto, tanto, parecia que nunca mais ia parar". (BRUM, 2008, p. 198)

A partir de Fortalece, Brum empreende uma complexa reflexão sobre a realidade do tráfico de drogas e dos jovens "falcões" que empunham pistolas e fuzis para defender a boca de fumo. Distante dos maniqueísmos que direcionam o campo de visão para termos essencialistas, centrados em antinomias frágeis como "bem" e "mal", o relato da repórter gaúcha nuança as diferenças existentes entre os "brasis" do morro e os "brasis" do asfalto. Compreende-se, dessa maneira, que Brum não enxerga a realidade como um dado acabado, mas como problemática, como pergunta incômoda, como interpelação do olhar. Esse raciocínio perpassa a narrativa que a autora de $O$ olho da rua tece sobre a realidade de Sérgio Cláudio o que resulta na cartografia de um conjunto de mapas sociais e na reconstrução de uma história individual.

\section{Mães vivas de uma geração morta}

De modo semelhante, na reportagem Mães vivas de uma geração morta, Brum perscruta a realidade do tráfico de drogas com a finalidade de compreender o ponto de vista das que restam, das que sobrevivem à morte dos filhos - as mães. A autora de $A$ vida que ninguém vê focaliza na narrativa os retratos de Selvina Francisca da Silva, Maria Fátima da Silva Souza, Enilda Rodrigues da Silva, Josefa Inácio Farias, Eva Sebastiana Araújo, Graça Mary Azevedo Carneiro, Helena Silva Cruz e Francisca Maria da Silva Porfírio - oito mães vivas de filhos perecidos.

De acordo com Mauro de Souza Ventura e Tayane Aidar Abib (2016, p. 341), o relato proposto por Brum aprofunda o conhecimento sobre o cotidiano das "mulheres que perderam seus filhos para o tráfico e que, tantas vezes, pela visão já estereotipada que circula nas mídias, foram despersonalizadas e tratadas como invisíveis". 
A autora de $O$ olho da rua destaca que a opção por relatar a guerra do tráfico de drogas sob o ponto de vista do testemunho das mães implica no exercício respeitoso de abertura do olhar para ver. Brum (2008, p. 241) salienta que o grande desafio que se apresenta ao jornalista é o de perceber "a realidade invisível - ou deliberadamente colocada nas sombras. Olhar para ver é o ato cotidiano de resistência de cada repórter, de cada pessoa".

Para abarcar as nuances e profundidades da realidade social, Brum (2008) coloca em evidência a necessidade da "complicação" da pauta como diretriz de inteligibilidade para os contextos jornalísticos e, por extensão, históricos e culturais. Desse modo, a reportagem Mães vivas de uma geração morta concede a Brum as chaves para uma leitura a contrapelo, isto é, para contestar uma visão universalizante e totalizadora presente no sintagma "mães de bandido".

Giovanni Levi (2016) observa que a micro-história resgata a complexidade das investigações, distancia-se das leituras esquemáticas e gerais e centraliza as análises nos comportamentos, escolhas e solidariedades histórico-socioculturais. De forma análoga, Brum (2008) direciona o exercício de sua prática para desvelar novas realidades e novos sujeitos. Ao selecionar as mães dos meninos do tráfico, a repórter pretende lançar luz sobre uma realidade atravessada por preconceitos, estereótipos e lugares-comuns.

Para a jornalista gaúcha, as mães dos meninos do tráfico são clivadas por duas indicações antagônicas. De um lado, servem para cuidar dos filhos da classe média, de outro, são marcadas pelo insucesso de cuidar dos próprios filhos. Atravessam as "fronteiras" da favela e da periferia "para prestar serviços que os de cá não querem fazer" (BRUM, 2008, p. 242). Da mesma forma, elas têm acesso a empregos mais precários e o ingresso aos territórios privilegiados da educação, da saúde e da dignidade lhes é negado. Nesses espaços, assevera Brum, as mães dos jovens são estrangeiras.

A autora de $A$ vida que ninguém vê explicita que a reportagem Mães vivas de uma geração morta foi elaborada tendo no horizonte a configuração de um olhar atento, respeitoso e ético, ou seja, uma contemplação detida e inclinada para 
as mães, buscando não só observá-las, mas efetivamente vê-las. Para garantir o desvelamento e a contextualização da realidade das oito mulheres, Brum recorre à reconstrução dos momentos, situações e contextos. A finalidade é "descobrir" novos significados sociais:

\begin{abstract}
A cada narrativa busquei contar não só das palavras, mas da forma de falar, dos gestos que desmentiam o que era dito, das repetições, das negações, dos silêncios. Como Eva da Brasilândia, que repetia três vezes o final de cada frase - e dizia que não sentia mais dor chorando. Eu queria dar ao leitor a oportunidade de ver pelos meus olhos os detalhes, as texturas, as ausências e os excessos de seu inferno pessoal - e também todas as nuances do que as fazia sobreviver. (BRUM, 2008, p. 242-243)
\end{abstract}

A reportagem de Eliane Brum (2008) aproxima-se da perspectiva assinalada por Levi (2016) da busca por um "resgaste da complexidade". O autor de A herança imaterial assinala que a micro-história atua na constituição dos momentos, acontecimentos e das realidades individuais sob o prisma da observação detida e singularizada dos sujeitos sociais, restaurando por meio da discussão e reflexão o peso e os matizes esmaecidos dos indivíduos. Conforme Levi, a microanálise possibilita tomar os fatos e os indivíduos como parâmetros para "a complexidade dos contextos nos quais os seres humanos agem" (LEVI, 2016, p. 23).

Aludindo ao pensamento de Ginzburg e Poni (1991), apreende-se que Brum se serve da articulação da escala reduzida e dos arranjos nominais para coser uma delicada trama em que estão dispostos problematicamente os indivíduos e os distintos estratos sociais. Em Mães vivas de uma geração morta, a repórter busca compreender, precisamente, quem são essas mulheres, que histórias seus rostos carregam e como sobrevivem ao "legado" da morte dos filhos.

Ao se contrapor às balizas do paradigma jornalístico, Brum opta por um percurso marcado pela compreensão dos conflitos sociais, pela complexidade, pelos vínculos, escolhas e pontos de vista. O encadeamento desse arranjo emerge na escrita da jornalista gaúcha como "perturbação" e "desordem", e não como uma hierarquia asséptica dos estamentos sociais. 
Partindo da perspectiva de "desacomodar", "perturbar" e "inquietar", Brum (2008) enreda os fios da vida das oito mães. O que as une, ressalta a repórter, é a relação umbilical de mulheres que "geram soldados - jamais comandantes para a narcopátria" (BRUM, 2008, p. 204). Os jovens são mortos por tiro, faca e granada, transformando a exceção dos dias em naturalizada repetição cotidiana. Ao sepultar um filho após o outro, "estas mulheres são lançadas um passo além da insanidade" (BRUM, 2008, p. 204).

A partir do estranhamento e do esforço para ver, isto é, da conjunção da busca por uma compreensão e por uma complexidade é que Brum vai revelar as vozes das mães dos mortos pelo tráfico. Uma dessas mães é Selvina Francisca da Silva, de 74 anos, moradora da Ceilândia, região administrativa do Distrito Federal. Selvina deu à luz doze filhos. Quatro foram mortos por tiro. Cinco morreram por doença. Um está desaparecido. Sobraram dois. Ao elaborar o relato sobre Selvina, Brum (2008) reconstrói sua vida de perdas. Primeiro Ihe foram as unhas, os dedos das mãos e dos pés. Depois o seu corpo foi marcado por queimaduras, acidentes e doenças. Contudo, como afirma Brum (2008), a dor que aflige Selvina é a da "morte sem esquecimento" dos filhos que foram assassinados.

Compreende-se, a partir de Selvina, que a redução da escala de análise possibilita a apreensão de novas realidades e o aprofundamento da vida dos sujeitos ao corroborar uma leitura intensiva dos contextos socioculturais marginalizados e invisibilizados. Desse modo, ao tecer o relato sobre a vida de Selvina, Brum a desloca da semântica que a sobredetermina - pobreza, "mãe de bandido" e lança sobre ela um olhar de respeito e uma escuta, que a aproximam das margens cognoscíveis e complexas das instâncias sociais. Esses aspectos podem ser percebidos no fragmento que segue, em que é apresentado o desenho social e histórico da moradora da Ceilândia:

Chegou antes da inauguração de Brasília, mas nunca encontrou lugar. Selvina teve acesso ao Plano Piloto apenas como empregada doméstica. Só entrava na arquitetura de Oscar Niemeyer para servir. Andou de invasão em invasão até fincar os pés incompletos na Ceilândia. Na cidade-satélite, benze o povo sem saúde. Em troca, não a deixam morrer de fome. 
Conseguiu enterrar três dos quatro filhos assassinados "no cemitério do plano, o mesmo de Juscelino". A última sepultou na cidade-satélite, brigando porque não podia pagar o preço exigido. "Sou brasileira e vou enterrar minha filha no Brasil nem que tenha de cavar uma cova fora do cemitério", disse ao encarregado.

Selvina é interrompida pela neta mais velha, órfã da filha assassinada em 25 de março num tiroteio entre traficantes. Tem dezessete anos. Está grávida. "Vó, minha bolsa estourou. Preciso ir pro hospital. Estou perdendo sangue".

A menina geme apertando a barriga espichada. O pai da criança está preso por assalto. Pela manhã, não havia o que comer. Selvina é dura no seu desespero: "Se aquieta, menina, que eu não tenho dinheiro. Vai ter que esperar".

Ergue as mãos mutiladas para o céu: "Meu comandante me disse que eu não temesse a ninguém...". (BRUM, 2008, p. 206-207)

Nesse caminho, ao observar as antinomias, as arestas e as lacunas deixadas pelo testemunho de Selvina, Brum (2008) articula algo próximo do que é defendido por Levi (1992). Para o autor de A herança imaterial, não se pretende abdicar do conhecimento individual em favor de uma "generalização mais ampla" e teleológica, mas, pelo contrário, direciona-se para acentuar "as vidas e os acontecimentos individuais" (LEVI, 1992, p. 158).

Sob esse ponto de vista, Eliane Brum (2008) procura conferir sentido à textura das palavras, das ausências e das assimetrias que povoam o mundo de Selvina. A maneira encontrada pela autora de $A$ vida que ninguém vê para que a moradora da Ceilândia pudesse ser notada para além das paragens de seu "mundo" situa-se na problematização dos contextos vivenciados e experimentados pela personagem e na compreensão de sua voz-testemunho. Selvina emerge como moduladora de um mapa social, cultural e histórico. Sua fala enuncia uma experiência habitual e corriqueira - quase sempre escondida nas brumas regulares do jogo cotidiano:

"Tenho muita lágrima. Choro de dia, choro de noite quando alembro que não tenho mais meta. Quatro filhos matados, um sumido. Quando morreu o terceiro, eu achei que fosse morrer também. Encomendei uma 
mortalha de tergal branco, muito bem costurada. Quem morreu, numa rixa de traficantes, foi minha filha. Botei nela a minha mortalha. Agora mandei costurar outra, mas azul. Agora eu quero ir de azul. Mortalha azul, caixão azul. Sou apaixonada pelo tempo. Esse mundão que Deus tem pra cima. Azul. Acabou tudo. Esse mundo foi ilusão". (BRUM, 2008, p. 229)

Em diálogo com Levi (1992), entende-se que a vida de Selvina e das demais mães é lida a partir do contexto da violência, da vulnerabilidade e da perda. Ao focalizar os percursos individuais, o relato de Brum desnuda uma variedade de experiências sociais, de modo que se processa uma exegese a partir das margens, dos anônimos e das dores inauditas. Nessa lógica, constata-se que a microanálise interpela os indivíduos, permitindo a composição de uma racionalidade e de uma complexidade dos fenômenos sociais. A investigação afasta-se de uma visão cartesiana de depreensão do mundo e assume, como indica Revel (2010, p. 438), "o problema da variação de escala e dos efeitos cognitivos que podem ser-Ihe associados".

Ventura e Abib (2016) ressaltam que a prática adotada por Eliane Brum se desvencilha das injunções tradicionais da atividade jornalística e materializa por meio da escrita um diálogo aprofundado sobre as problemáticas sociais. É o que pode ser notado no relato sobre Eva Sebastiana Araújo, de 55 anos, da Brasilândia, zona norte de São Paulo. Com os três filhos mortos, Eva fia-se na ideia de esquecimento, como se não lembrar aplacasse a rotina de dores.

Compreende-se que a base analítica utilizada por Brum (2008) se reveste de sensibilidade e solidariedade, ao trazer para a superfície o relato, os detalhes e as nuances do outro contrastante encarnado em Eva Sebastiana Araújo. Entendese, assim, que reduzir a complexidade da existência de Eva ao sintagma "mãe de bandido", apenas simplifica-a sem entendê-la, ao reforçar, exclusivamente, uma faceta dentre todas as possíveis. Desse modo, ao apresentar a perspectiva das mães, Brum descondiciona o olhar:

Noite e dia ela ouve um tambor dentro da cabeça. "Eu todo dia olho pro céu e não acredito que estou aqui e não no hospício. Não acredito, não acredito, não acredito", diz. Eva repete pelo menos três vezes o final das frases. Como se precisasse repetir para acreditar. Avisa que esqueceu tudo. "Depois que perdi esses meninos meus, minha cabeça está tão ruim que não 
lembro mais de nada, nada, nada", ressoa. "Pedi muito a Deus que tirasse a memória". E então lembra de tudo, cada detalhe. Aos 55 anos, o que Eva perde não é a memória, mas os dentes. Desde que o terceiro filho morreu, eles amolecem e caem. "Pronto. Perdi tudo. Morreu tudo. Tudo, tudo, tudo."

Ao iniciar sua narrativa de morte, Eva avisa: "Fiquei fria, não choro mais, não sinto mais nada. Nada, nada, nada". Então começa a chorar e não para mais até o ponto final. A história de sua vida sai encharcada. Zeus, na mitologia grega, compadeceu-se do pranto de Níobe, cujos sete filhos e sete filhas foram mortos. Na lenda ele transformou aquela mãe numa rocha que verte água. Foi a forma encontrada pelos antigos para representar a dor sem nome. Mães que perdem filhos assassinados são pedras que choram. (BRUM, 2008, p. 207-208)

A compreensão minuciosa sobre as mães dos mortos pelo tráfico possibilita o avizinhamento de suas histórias e de seus rostos. Ventura e Abib (2016) pontuam que o relato de Brum, distante dos postulados que configuram a prática jornalística hegemônica, corporifica a presença do outro como uma interpelação ao leitor, arregimentando as texturas e as vozes dissonantes. De forma que em Mães vivas de uma geração morta, o reconhecimento não emerge como mero enunciado, mas como expansão do "olhar que olha para ver", numa aliança reflexiva de sensibilidades, diálogos, afetos e perplexidades.

Brum (2008) se afasta dos ditames hierárquicos de relacionamento com as fontes, sua postura busca trazer para o relato da reportagem as vivências, a oratura e o universo linguístico e simbólico das personagens. Para alcançar esse objetivo, a autora opta por uma escuta atenta e rigorosa das entrevistadas.

Esse posicionamento pode ser verificado no desenho sobre a vida de Graça Mary Azevedo Carneiro, moradora da zona norte do Rio de Janeiro. Os três filhos foram mortos, só restaram os netos. Graça diz que vive em um país cindido não há formalmente uma fronteira dividindo a favela do asfalto; contudo, ela permanece presa a uma redoma invisível de impossibilidades. Graça fala que não tem dinheiro para sair da favela e que se sente aprisionada. Aponta que para além dos limites da comunidade, ninguém percebe a guerra cotidiana a que todos estão sujeitos: "Eu sinto tanto medo, o tempo todo. Queria me esconder embaixo da terra. Embaixo da terra eu me sentiria segura" (BRUM, 2008, p. 210). 
Verifica-se também com Josefa Inácio Farias e com Francisca Maria da Silva Porfírio a articulação sinuosa de uma estatística que se repete. O filho de Josefa foi morto supostamente pela polícia. Brum (2008) apresenta para o leitor o depoimento completo da mãe. A finalidade é estabelecer uma proximidade social, afetiva e complexa com a realidade do outro:

Os tiros começaram desse lado da favela logo cedo. Mandei minha filha procurar saber. Ela encontrou o irmão morto. Encurralaram ele. Levou um tiro na barriga que atravessou. Disseram: o único trabalho que vão ter com esse aqui agora é enterrar. Guardei a roupa encharcada de sangue do meu filho. Era um menino bom. Bateram nele. Tava todo roxo, o braço quebrado. Quando vi o rosto dele assim, no caixão, perdi coragem. Era eu que tinha de ir primeiro. (BRUM, 2008, p. 225)

Ao mesmo tempo em que tece uma geografia da violência, o relato sobre as mães possibilita pensar o jornalismo próximo ao que é defendido por Sylvia Moretzsohn (2007), como conhecimento específico associado à vida cotidiana e ao esclarecimento. Desse modo, busca-se "identificar as possibilidades e as limitações dessa prática profissional, confrontada com as condições de produção dominantes" (MORETZSOHN, 2007, p. 29).

Infere-se, por conseguinte, que a orientação para o esclarecimento "já pressupõe a necessidade de um recuo para a reflexão" (MORETZSOHN, 2007, p. 29). O olhar desacomodado observado na prática de Brum encaminha-se para o desvelamento de realidades costumeiramente naturalizadas. O relato verificado na reportagem Mães vivas de uma geração morta se distancia da fixidez do discurso colonial apontado por Homi Bhabha (2013, p. 117) na "construção ideológica da alteridade". Logicamente que o discurso do colonialismo é ambivalente e se expressa sob o signo de uma distinção cultural, racial e histórica. Desse modo, o discurso colonial encontra eco no que se define como estereótipo, ao configurar

[...] uma forma de conhecimento e identificação que vacila entre o que está sempre "no lugar", já conhecido, e algo que deve ser ansiosamente repetido... como se a duplicidade essencial do asiático ou a bestial liberdade sexual do africano, que não precisam de prova, não pudessem na verdade ser provados jamais no discurso. (BHABHA, 2013, p. 117) 
Na reportagem Mães vivas de uma geração morta, são observados os dois movimentos. O primeiro que se inter-relaciona ao pressuposto aventado por Moretzsohn (2007), da necessidade de uma desnaturalização dos fatos. E o segundo que aponta para a ambivalência do discurso colonial em diálogo com a leitura empreendida por Bhabha (2013). Tomando de partida os dois arranjos, constata-se que a realidade das mães se encaminha para a complexidade da vida social nas comunidades e nas favelas, de um lado; e para o entendimento de uma resistência política e cognitiva, de outro.

Ao focalizar a investigação sobre a trajetória individual das mães, emergem realidades como a de Francisca Maria da Silva Porfírio. Sob o vértice das margens, a reportagem arquiteta contextos e referenciais comumente elididos dos espaços de debate, visibilidade e conhecimento.

Francisca trabalhou dos dez aos 48 anos em casa de família, no Rio de Janeiro. Sua carteira de trabalho nunca foi assinada. Uma vida inteira sem o mínimo de salário. Brum (2008, p. 210) narra que quando Francisca sofreu um infarto "não teve direito a pensão nem aposentadoria". O filho, antes de ser assassinado, desempenhou atividades como açougueiro, gari, entregador de verduras e fez curso de segurança. Entretanto, depois de um ano sem emprego, virou traficante:

Durou um ano vivo. "Ele ganhava 1.500 reais por semana. Pagava meus remédios, passagem, prestação do guarda-roupa, gás, tudo", diz Francisca. "Não era o que eu desejava para ele. Sonhava que fosse mecânico. Mas eu aceitava o dinheiro porque não tinha opção."

Ao chegar do trabalho, o filho deixava o fuzil no portão. Como se fosse a caixa de ferramentas. "Meu filho, não quero esses brinquedos perigosos dentro de casa", Francisca dizia. Como bom filho, ele obedecia. Enquanto ela tirava o almoço, ele tomava banho. Francisca lavava e consertava suas roupas, velava o sono. Só quando os fogos pipocavam na favela, avisando da entrada da polícia, a mãe era obrigada a lembrar que a empresa em que o filho trabalhava não era comum. Nem legal.

Em março, ele não voltou. "Desde que morreu, estou sem dinheiro para comprar todos os remédios, a prestação dos óculos venceu. Ficou tudo difícil". Francisca começa a contar como o filho morreu e passa mal. Diz que é o coração. A filha corre, Ihe dá remédio. "Quem mora no asfalto 
tem medo de nós, acha que gente da favela é bicho", diz a garota. Falta o ar a Francisca. (BRUM, 2008, p. 210-211)

Recorrendo ao pensamento de Igor Sacramento (2014), constata-se que a vida de Francisca, assim como das outras mães, é tecida sob o ponto de vista de uma "biografia dialógica". Nesse processo são acionados os movimentos individuais, relacionando-os a conjunturas sociais específicas.

Para Sacramento (2014, p. 165), a trajetória individual é cruzada por algumas balizas. A primeira delas aponta que o processo de constituição do indivíduo é "sempre semialheio", porque emerge de contextos "dialógicos de produção de sentidos". Do mesmo modo, as ações de consumo, produção e circulação que caracterizam as materialidades e linguagens de uma vida despontam como "prática discursiva dialógica", isto é, atuam na definição social, cultural e histórica do sujeito. Em diálogo com Bourdieu, Sacramento enuncia mais um ponto: o fato de que a trajetória individual não deve ser percebida no âmbito de uma universalidade e totalidade, mas, pelo contrário, a partir das possibilidades, frestas e negociações. Sacramento explicita ainda que

4) a trajetória individual é um evento vivo, justamente porque se trata de um pôr em ação discursos, interesses e motivações que têm localizações sociais e históricas distintas que, nessa complexidade performática, forma um todo orgânico e múltiplo; e 5) as formas de sociabilidade e relações com outros indivíduos são mediadas pelas conjunturas e estruturas existentes e atuantes no interior de determinado campo e em dada situação [...]. (SACRAMENTO, 2014, p. 166)

Maria, de 48 anos, é ex-operária. O filho entrou para o tráfico aos doze anos como "avião". Por conta da dependência, aos dezessete já não servia para o negócio. Maria relata que o filho morreu aos 25 anos, devido a um desentendimento com o traficante. Perdeu a vida por um real. Quando o filho ficou incontrolável e começou a destruir as coisas de casa, todos foram embora, Maria ficou.

Ela internou o garoto em clínica, bateu, gritou; contudo, não houve forma de afastá-lo das drogas. Maria fala que quando notou que não havia maneira de distanciá-lo do crack, arrumou "um lugar em casa só para ele usar a pedra sem 
que ninguém visse, porque não tinha dinheiro pra tirar ele da cadeia" (BRUM, 2008 , p. 212). Como forma de entender o universo problemático dos garotos envolvidos com o crime, Brum (2008) desnuda o relato de Maria, deixando-a falar e organizar os sentidos de seu sofrimento e de sua vida:

\footnotetext{
"Um dia eu não suportei. Só tinha eu e meu filho dentro de casa. Ele tinha catorze anos. E eu não sabia mais o que fazer. Decidi botar fogo em nós dois. Saí de casa pra comprar álcool. A dona da mercearia viu como eu estava e não quis me vender. Então fui bater na outra mercearia, mas estava fechada. Voltei para casa, me deitei na cama e não me lembro de mais nada. Os vizinhos disseram que eu comecei a gritar. Eu sabia que meu filho ia acabar morrendo. Era insuportável. Aconteceu anos depois. Foi assassinado pelo traficante. Eu juntei o corpo do meu filho do chão. Lembrei que o sonho dele era doar os órgãos. Só prestaram os rins e as córneas. $O$ resto a pólvora estragou. Era daquelas balas que explodem por dentro". (BRUM, 2008, p. 221)
}

De modo semelhante, Brum (2008) revela os detalhes da realidade da lavadeira Enilda Rodrigues da Silva, de 44 anos, da periferia de Fortaleza, no Ceará. Ao se deter na compreensão localizada e singular da personagem, a autora de O olho da rua possibilita ao leitor se aproximar e conhecer as bases do universo, os traços do cotidiano e as experiências dessa mãe.

Enilda começou a pagar o caixão do filho com o rapaz ainda vivo. Todos os meses ela pagava quinze reais pelo carnê. O valor correspondia a pouco mais da metade do que ela ganhava para lavar, engomar e passar. O filho morreu aos vinte anos, pouco antes do Natal. Brum (2008) relata que Enilda empenha-se agora no pagamento do caixão do filho de dezenove anos que "ainda está vivo".

A partir da observação reduzida da realidade de Enilda, a autora de $A$ vida que ninguém vê desvela ao leitor as marcas de uma geografia social caracterizada pelo apagamento, pela vulnerabilidade e por uma subalternização das histórias comuns, das pessoas simples, dos sujeitos colocados à margem.

A vida de Enilda, em específico, é caracterizada por Eliane Brum como um "conto de horror", porque somente o horror pode simbolizar o desespero "de uma mãe que compra o caixão de filhos com saúde e menos de vinte anos de idade" (BRUM, 
2008, p. 213). Nessa direção, Brum (2008) compreende que a compra do caixão representa para Enilda a possibilidade de conferir dignidade para os filhos - dignidade não alcançada em vida, mas, paradoxalmente, encontrada na morte:

\begin{abstract}
Não encontrasse um sentido, Enilda não suportaria a insanidade contida no ato de pagar adiantado os sete palmos de chão de um filho após o outro. São perguntas simples que cruzam a cabeça nessa hora. Como ela esfrega, engoma e passa mais de setenta peças de roupa, na mão, e ao final ganha 25 reais? Como seu marido acorda às três da madrugada para fazer pão até a noite para receber oitenta reais por mês? Não seria essa a notícia? Que eles ignorem a exploração explícita do trabalho, a indignidade de suas condições de vida, e decidam que seu ato de resistência é ser honesto? (BRUM, 2008, p. 215)
\end{abstract}

A adoção da microanálise aprofunda a realidade das oito personagens presentes na reportagem Mães vivas de uma geração morta sob o vértice da apreensão da experiência social. Em conversa com o pensamento de Revel (2010, p. 438), confirma-se que "reduzir o campo da análise significava [...], dar os meios de colocar em relação e [...] de integrar as diferentes dimensões dessa experiência social". Em contiguidade com esse pensamento, Brum (2008) assevera que a reportagem possibilitou a aproximação dos diferentes brasis - das favelas e das periferias com o Brasil do "asfalto".

\title{
Considerações finais
}

Observa-se que o percurso jornalístico delineado por Eliane Brum se guia por uma proposta de tessitura de visibilidades que, pari passu, engendra algo próximo daquilo que Boaventura de Sousa Santos (2010) define como postulado de resistência epistemológica. Compreende-se que ao enunciar realidades e sujeitos sombreados por discursos hegemônicos, Brum (2008) evidencia distintos saberes culturais e históricos - permitindo a emergência singularizada de sensibilidades individuais e de grupos sociais.

Os arranjos microanalíticos observados na prática de Brum problematizam lugares e sujeitos cujas histórias são marcadas por rígidos parâmetros de opacidade. 
Ao atravessar os limiares que opõem "favela" e "asfalto", é possível estabelecer uma proximidade e se abrir para conhecer experiências obliteradas social, cultural, histórica e jornalisticamente. Esse movimento é observado em Expectativa de vida: vinte anos e em Mães vivas de uma geração morta quando o olhar da repórter considera respeitosa e detidamente as nuances do mundo habitado pelos personagens.

Pensar a narrativa jornalística de Eliane Brum a partir do arcabouço teórico da micro-história italiana constitui um trabalho de reflexão necessário, porque permite trazer para o primeiro plano as discussões sobre os anônimos e a constituição microanalítica dos contextos sociais e culturais. Desse modo, os referenciais metodológicos discutidos durante o estudo podem servir como aportes para novas pesquisas, tendo a vida cotidiana, os sujeitos subalternos e as dimensões socioculturais como espaços de discussão, reflexão e de construção de novos olhares, relatos e saberes.

\section{Referências}

BRUM, E. A vida que ninguém vê. Porto Alegre: Arquipélago Editorial, 2006.

BRUM, E. O olho da rua: uma repórter em busca da literatura da vida real. São Paulo: Globo, 2008.

BHABHA, H. K. O local da cultura. Tradução de Myriam Ávila, Eliana Lourenço de Lima Reis e Gláucia Renate Gonçalves. Belo Horizonte: Editora UFMG, 2013.

GINZBURG, C. O fio e os rastros: verdadeiro, falso, fictício. Tradução de Rosa Freire d'Aguiar e Eduardo Brandão. São Paulo: Companhia das Letras, 2007. 
GINZBURG, C.; PONI, C. O nome e o como: troca desigual e mercado historiográfico. In: GINZBURG, C.; PONI, C.; CASTELNUOVO, E. (org.). A microhistória e outros ensaios. Tradução de António Narino. Rio de Janeiro: DifelBertrand Brasil, 1991. p. 169-178.

LEVI, G. 30 anos depois: repensando a micro-história. In: VENDRAME, M. I.; KARSBURG, A.; MOREIRA, P. R. S. Ensaios de micro-história: trajetória e imigração. São Leopoldo: Oikos, 2016. p. 18-31.

LEVI, G. Sobre a micro-história. In: BURKE, P. (org.). A escrita da história: novas perspectivas. São Paulo: Editora Unesp, 1992. p. 133-161.

LIMA, H. E. A micro-história: escalas, indícios e singularidades. Rio de Janeiro: Civilização Brasileira, 2006.

MORETZSOHN, S. Pensando contra os fatos: jornalismo e cotidiano - do senso comum ao senso crítico. Rio de Janeiro: Revan, 2007.

QUEIRÓS, F. A. T. Brechas da narrativa e profundezas do cotidiano: micro-história italiana e jornalismo em O olho da rua, de Eliane Brum. 2020. Tese (Doutorado em Ciências da Comunicação) - Universidade do Vale do Rio dos Sinos, Vale do Rio dos Sinos, 2020.

REVEL, J. Micro-História, macro-história: o que as variações de escala ajudam a pensar em um mundo globalizado. Revista Brasileira de Educação, Rio de Janeiro, v. 15, n. 45, p. 434-444, 2010. Disponível em: http://www.scielo.br/pdf/rbedu/ v15n45/03.pdf. Acesso em: 20 jan. 2018. 
SACRAMENTO, I. A biografia do ponto de vista comunicacional. Revista Matrizes, São Paulo, v. 8, n. 2, p. 153-173, 2014. Disponível em: https://doi.org/10.11606/ issn.1982-8160.v8i2p153-173. Acesso em: 29 mar. 2017.

SANTOS, A. C. A contribuição da micro-história para o campo da comunicação: uma abordagem historiográfica a partir da trajetória de homens comuns. In: CONGRESSO BRASILEIRO DE CIÊNCIAS DA COMUNICAÇÃO, 38., 2014, Foz do Iguaçu. Anais [...]. Foz do Iguaçu, 2014. Disponível em: http://www.intercom. org.br/papers/nacionais/2014/resumos/R9-2443-1.pdf. Acesso em: 19 fev. 2019.

SANTOS, B. S. Para além do pensamento abissal: das linhas globais a uma ecologia de saberes. In: SANTOS, B. S.; MENESES, M. P. (org.). Epistemologias do Sul. São Paulo: Cortez, 2010. p. 31-83.

VENTURA, M. S.; ABIB, T. A. Sensibilidade, dialogia e afetos no jornalismo: articulações para a ampliação do horizonte de compreensão do Outro. Razón y Palabra, Quito, v. 20, n. 2-93, p. 333-345, 2016. Disponível em: https://www.revistarazonypalabra. org/index.php/ryp/article/view/21. Acesso em: 15 jul. 2017.

submetido em: 26 abr. 2020 | aprovado em: 19 set. 2020 